\title{
STUDY OF CERAMIC-POLYMER COMPOSITES RELIABILITY BASED ON THE BENDING STRENGTH TEST
}

\section{OCENA NIEZAWODNOŚCI KOMPOZYTÓW CERAMICZNO-POLIMEROWYCH NA PODSTAWIE PRÓBY WYTRZYMALOŚCI NA ZGINANIE}

\author{
Agata Walczak $^{1}$, Daniel Pieniak ${ }^{2}$, Andrzej Niewczas ${ }^{2}$, \\ Agata M. Niewczas ${ }^{3}$, Pawel Kordos ${ }^{4}$ \\ ${ }^{1}$ Main School of Fire Services, ${ }^{2}$ High School of Economics and Innovations \\ ${ }^{3}$ Medical University in Lublin, ${ }^{4}$ University of Technology in Lublin
}

\begin{abstract}
In this paper the reliability assessment of structural reliability of the selected light-cured dental composites based on the biaxial flexural strength test results has been presented. A two-parameter Weibull distribution was applied as a reliability model in order to estimate probability of strength maintenance in the analysed population. Weibull distribution parameters were interpreted as a characteristic material strength (scale parameter) and structural reliability parameter in terms of ability to maintain strength by each of specimen from the general population (shape parameter). 20 composite specimens underwent strength tests, including 2 "flow" type composites and 2 standard composites (with typical filler content). "Flow" type composites were characterized with lower characteristic strength and higher structural reliability comparing to other studied composites.
\end{abstract}

Keywords: dental composites, strength, reliability analysis

Streszczenie: $W$ artykule przedstawiono ocenę niezawodności strukturalnej wybranych światloutwardzalnych kompozytów stomatologicznych na podstawie wyników testu wytrzymatości na zginanie dwuosiowe. Wykorzystano dwuparametrowy rozklad Weibull'a jako model niezawodności w celu oszacowania prawdopodobieństwa zachowania wytrzymałości materiału $w$ analizowanej populacji. Parametry rozkladu Weibull'a interpretowano jako wytrzymałość charakterystyczna materiału (parametr skali) oraz wskaźnik niezawodności strukturalnej w sensie zdolności do zachowania charakterystycznej wytrzymałości przez każdy z egzemplarzy populacji generalnej (parametr ksztaltu). Próbie wytrzymałościowej poddano po 20 próbek kompozytów, $w$ tym 2 kompozyty typu, ,flow" oraz 2 kompozyty standardowe (z typowa ilościa wypetniacza). Kompozyty typu ,flow" charakteryzowaty się niższa wytrzymatościa charakterystyczna oraz wyższa niezawodnościa strukturalna $w$ porównaniu z pozostalymi badanymi kompozytami.

Stowa kluczowe: kompozyty stomatologiczne, wytrzymałość, analiza niezawodności 
Study of ceramic-polymer composites reliability based on the bending strength test Ocena niezawodności kompozytów ceramiczno-polimerowych na podstawie...

\section{Introduction}

Clinical studies indicates that one of the main reasons of dental composite fillings failures is composite cracking $[2,12,18]$. Therefore, in in vitro studies conducted in order to determine characteristics of the studied material in the conditions close to reality, an important aspect is a mechanical strength. It depends on many factors such as microstructure and composite failure process, as well as type of research method and environment $[6,15]$. According to ISO 4049 standard [14] related to dental composite materials used for re-construction of hard teeth tissues, material strength is determined in three-point flexural strength test. In the literature examples of the use of some other research methods can be found, including biaxial flexural strength test $[11,19,17]$.

Biaxial flexural strength study is included in technical standard ISO 6872 [13]. In this method a tensile stress occurs in central part of the specimen. It decreases by dispersion over larger area, thus by increasing radius between area where stress occurred and centre of the sample [1,5]. The advantage of this study method is a round shape of the specimen. Occurrence of the maximum stress in the central part of the specimen prevents formation of cracks on the edges. What is more, the area of stress occurrence is smaller than in case of three-point bending test, therefore there is a lower probability of stress occurrence on the surface with defects. It is worth mentioning that polymerization process of the round samples is more repeatable. Additionally, a direction and distribution of internal stresses generated as a result of this process and polymerization shrinkage has a lower influence on the result of strength test.

Mechanical strength describes material's behaviour subject to static loads. One of the most important factors influencing ceramic-polymer composites strength is size and distribution of random deviations in the structure of the single specimen of the studied material. In order to perform a general assessment of the material it is necessary, besides strength determination in the studied random sample, to determine probability of strength behaviour in the studied population. For the forecast of the above defined structural reliability Weibull distribution can be applied $[3,9,10,15]$. Weibull distribution modulus ( $\mathrm{m}$, shape parameter) is taken as a distribution of material strength in the considered manufactured series [7]. High value of shape parameter indicates probability of lower number of random defects occurrence in the composite and potentially higher reliability in the clinical use. Weibull distribution parameter $\sigma_{0}$, (scale parameter), is described as a characteristic material strength value, which reflects $63.2 \%$ cases of material failure.

The objective of this paper was to perform the structural reliability evaluation of the selected light-cured ceramic-polymer composites based on the biaxial flexural strength test. 


\section{Material and method}

The following four light-cured ceramic-polymer composites were studied: Filtek Z500, Filtek Flow, Flow Art and F2. Basic data of the above mentioned materials are included in tab. 1.

Tab. 1. List of studied materials

\begin{tabular}{|c|c|c|c|l|c|c|}
\hline No & Material & Manufacturer & Type & $\begin{array}{c}\text { Type and size of filler } \\
\text { particles }\end{array}$ & $\begin{array}{c}\text { Content } \\
\text { of filler } \\
\text { particles } \\
\text { (\% wt.) }\end{array}$ & $\begin{array}{c}\text { Content } \\
\text { of filler } \\
\text { particles } \\
\text { (\% vol. })\end{array}$ \\
\hline $\mathbf{1}$ & $\begin{array}{c}\text { Filtek } \\
\mathbf{Z 5 0 0}\end{array}$ & $\begin{array}{l}3 \mathrm{M} \text { ESPE } \\
\text { (USA) }\end{array}$ & Nanocomposite & $\begin{array}{l}\mathrm{SiO}_{2} 20 \mathrm{~nm}, \mathrm{ZrO}_{2} / \mathrm{SiO}_{2} \\
5-20 \mathrm{~nm}, \quad(0.6-1.4 \mu \mathrm{m} \\
\text { clusters) }\end{array}$ & $78,5 \%$ & $59,5 \%$ \\
\hline $\mathbf{2}$ & $\begin{array}{r}\text { Filtek } \\
\text { Flow }\end{array}$ & $\begin{array}{l}3 \mathrm{M} \text { ESPE } \\
\text { (USA) }\end{array}$ & $\begin{array}{l}\text { Microhybrid } \\
\text { "flow" type }\end{array}$ & $\begin{array}{l}\text { ZrO} / \mathrm{SiO}_{2} \\
0.01-6 \mu \mathrm{m} \\
\text { average: } 1.5 \mu \mathrm{m}\end{array}$ & $68 \%$ & $47 \%$ \\
\hline $\mathbf{F l o w}$ & $\begin{array}{l}\text { Arkona } \\
\text { L.F.S. } \\
\text { (Poland) }\end{array}$ & $\begin{array}{l}\text { Microhybrid } \\
\text { "flow" type }\end{array}$ & $\begin{array}{l}\text { barium-alumino- } \\
\text { silicate glass, } \\
\text { fumed silica, titanium } \\
\text { dioxide } \\
\text { average: } 0.76 \mu \mathrm{m}\end{array}$ & $64 \%$ & No data \\
\hline $\mathbf{F 2}$ & $\begin{array}{l}\text { Arkona } \\
\text { L.F.S. } \\
\text { (Poland) }\end{array}$ & Microhybrid & $\begin{array}{l}\text { fluoro-barium- } \\
\text { alumino-silicate glass } \\
\text { average: } 0.90 \mu \mathrm{mm}\end{array}$ & $79 \%$ & No data \\
\hline
\end{tabular}

Biaxial flexural strength test was conducted on 20 composite specimens of each type $(N=20)$. The specimens were disc-shape with diameter of $13 \mathrm{~mm}$ and thickness of $2 \mathrm{~mm}$, they were exposed to LED lamp for $40 \mathrm{sec}$. Before tests were initiated the specimens had been kept in artificial saliva at $37^{\circ} \mathrm{C}$ for 3 months. Tests were conducted using strength machine Zwick/Roell Z100. The specimens were placed on three steel balls (fig. 1). Supports were located on the circle perimeter with circle diameter of $10 \mathrm{~mm}$, angle between the supports was $120^{\circ}$. The specimens were loaded through the flat piston (fig. 1). Crosshead speed was $0.5 \mathrm{~mm} / \mathrm{min}$.
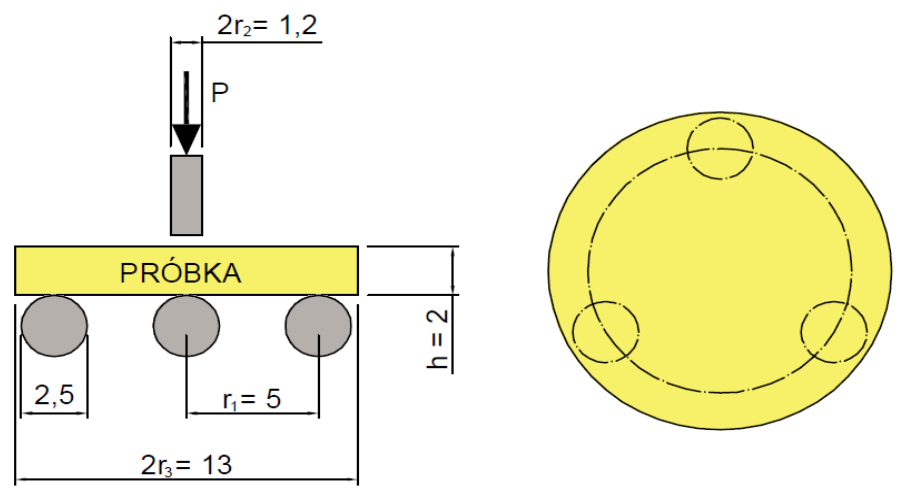

Fig. 1 Schematic diagram of the piston-on-three-ball biaxial strength test 
Study of ceramic-polymer composites reliability based on the bending strength test Ocena niezawodności kompozytów ceramiczno-polimerowych na podstawie...

Based on the biaxial bending test a maximum tensile strength was determined $\sigma_{\mathrm{BI}}$, using the following formula:

$$
\begin{gathered}
\sigma_{B I}=\frac{-0.2387 P(X-Y)}{h^{2}} \\
X=(1+v) \ln \left(\frac{r_{2}}{r_{3}}\right)^{2}+\left[\frac{1-v}{2}\right]\left(\frac{r_{2}}{r_{3}}\right)^{2} \\
Y=(1+v)\left[1+\ln \left(\frac{r_{1}}{r_{3}}\right)^{2}\right]+(1-v)\left(\frac{r_{1}}{r_{3}}\right)^{2}
\end{gathered}
$$

where:

$\mathrm{P}$ - failure load, $\mathrm{N}$,

$\mathrm{h}$ - specimen height, $\mathrm{mm}$,

$v$ - Poison's ratio, for all composites $v=0,24$ [12],

$\mathrm{r}_{1}$ - radius of the support ball circle, $\mathrm{r}_{1}=5 \mathrm{~mm}$,

$r_{2}$ - radius of loaded area, $r_{2}=0,6 \mathrm{~mm}$,

$\mathrm{r}_{3}$ - specimen's radius, $\mathrm{mm}$.

\section{Study results}

\section{Descriptive statistics of study results}

Table 2 presents descriptive statistics and Weibull distribution parameters determined based on strength study results: specimens number $(N)$, average value (average), median $(\mathrm{Q} 2)$, quartile one $(\mathrm{Q} 1)$ and three $(\mathrm{Q} 3)$, dispersion, standard deviation and coefficient of variation, as well as Weibull modulus (m) and characteristic strength $\left(\sigma_{0}\right)$. For the analysis purpose strength results were grouped based on the composite type: Filtek Z500, Filtek Flow, Flow Art, F2 (respectively

\begin{tabular}{|c|c|c|c|c|c|c|c|c|c|c|}
\hline \multirow{2}{*}{ Material } & \multirow[t]{2}{*}{$\mathrm{N}$} & Average & Q2 & Q1 & Q2 & Dispersion & St.dev & \multirow{2}{*}{$\begin{array}{c}\text { Coeff. } \\
\text { Var. } \\
{[\%]}\end{array}$} & \multirow{2}{*}{$\begin{array}{c}\sigma_{0} \\
{[\mathrm{MPa}]}\end{array}$} & \multirow[t]{2}{*}{$\mathrm{m}$} \\
\hline & & \multicolumn{6}{|c|}{ [MPa] } & & & \\
\hline FZ500 & 20 & 116.75 & 115.31 & 112.28 & 126.06 & 34.47 & 9.97 & 8.54 & 121.24 & 13.58 \\
\hline FFlow & 20 & 93.10 & 94.10 & 91.57 & 94.83 & 18.81 & 4.60 & 4.94 & 95.30 & 22.96 \\
\hline $\begin{array}{l}\text { Flow } \\
\text { Art }\end{array}$ & 20 & 85.63 & 86.69 & 80.74 & 88.62 & 13.87 & 4.31 & 5.03 & 87.683 & 21.88 \\
\hline $\mathrm{F} 2$ & 20 & 114.55 & 114.60 & 94.47 & 136.79 & 80.78 & 23.33 & 20.37 & 123.93 & 5.79 \\
\hline
\end{tabular}
FZ500, FFlow, FlowArt, F2).

Tab. 2. Descriptive strength statistics and Weibull distribution parameters 


\section{Reliability analysis}

Conducted analysis shall be seen as an attempt to assess the probability of maintaining standards of material strength in the whole population, thus as a repeatability of the obtained results in the whole population.

Reliability analysis was conducted assuming Weibull distribution as a probability distribution model of the failure of studied composites at the biaxial bending test conditions. Failure probability $\mathrm{P}_{\mathrm{f}}$, is described here by Weibull distribution function with the following formula:

$$
P_{f}=1-\exp \left[-N\left(\frac{\sigma-\sigma_{\mathrm{u}}}{\sigma_{0}}\right)^{m}\right]
$$

where:

e - constant $(\mathrm{e}=2.71828 \ldots)$,

$\mathrm{N}$ - number of samples,

$\sigma$ - failure stress,

$\sigma_{\mathrm{u}}$ - location parameter (stress value corresponding to probability of failure close to 0 ),

$\sigma_{0}$ - scale parameter,

$\mathrm{m}$ - shape parameter.

Number of specimens of each type of material was 20, therefore in the equation (4) it was possible to make a simplification of neglecting $N$ value $[4,16]$. Due to a random nature of defects occurrence in the studied composite specimens it was assumed that location parameter $\sigma_{\mathrm{u}}=0$. After considering the above assumptions the equation (4) will have the following form:

$$
P_{f}=1-\exp \left[-\left(\frac{\sigma}{\sigma_{0}}\right)^{m}\right]
$$

The above equation after taking the logarithm can be simplified to the linear form:

$$
\ln \left[\ln \left(\frac{1}{1-P_{f}}\right)\right]=m \ln (\sigma)-m \ln \left(\sigma_{0}\right)
$$

where:

$$
P_{f}=\frac{x-0.5}{N}
$$

$\mathrm{x}$ - specimen number after "ranking" according to strength values.

Based on the equation (6) a survival probability $\left(\mathrm{P}_{\mathrm{s}}\right)$ can be obtained, since $1-\mathrm{P}_{\mathrm{f}}=$ $\mathrm{P}_{\mathrm{s}}$, thus:

$$
\ln \left[\ln \left(\frac{1}{P_{s}}\right)\right]=m \ln (\sigma)-m \ln \left(\sigma_{0}\right)
$$


Study of ceramic-polymer composites reliability based on the bending strength test Ocena niezawodności kompozytów ceramiczno-polimerowych na podstawie...

Equation (8) enables determination of non-parametric survival probability curve $P_{s}$, necessary for estimation of Weibull distribution parameters. Intersection point of $Y$ axis by approximation function depends on $-m \ln \left(\sigma_{0}\right)$, while slope parameter of approximation function is a shape parameter of Weibull distribution $m$ [8].

The linear approximation of the strength test results, regression equations and determination coefficients after logarithmic transformation are presented in figure 2 .

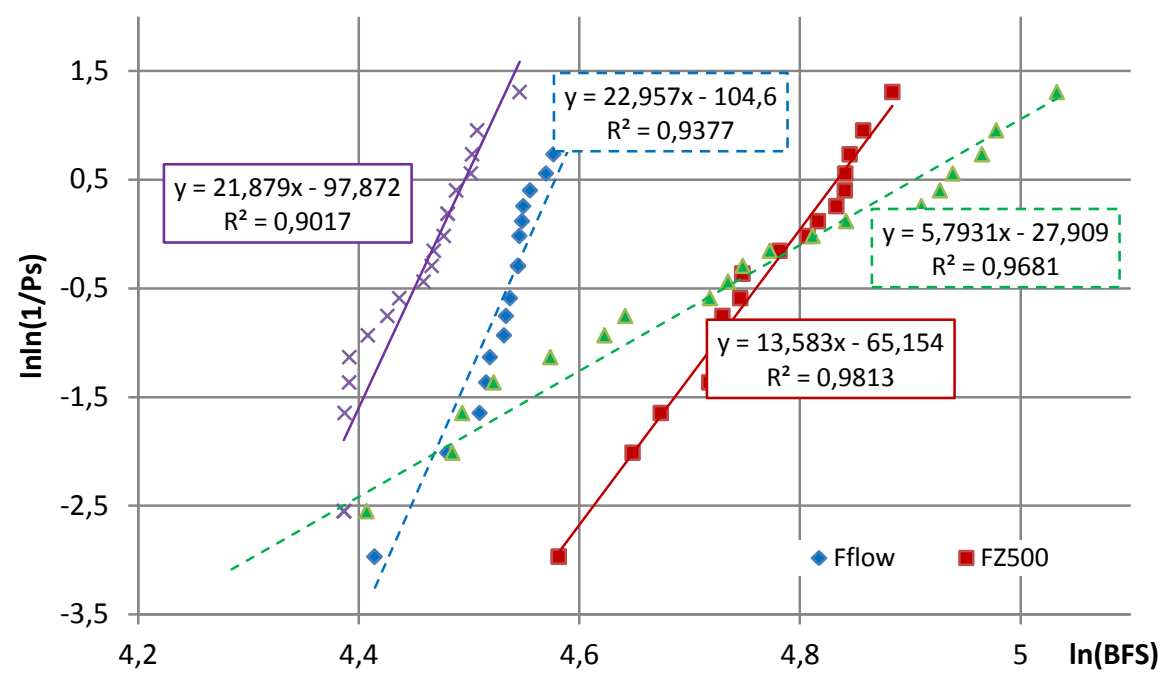

Fig.2 Approximation of survival probability distribution

Empirical failure function curves (Weibull distribution function) based on strength results of the studied composites is presented in figure 3 . In the figure a red dotted line indicates probability level of failure $\mathrm{P}_{\mathrm{f}}=0,632$ corresponding to characteristic strength $\sigma_{0}$.

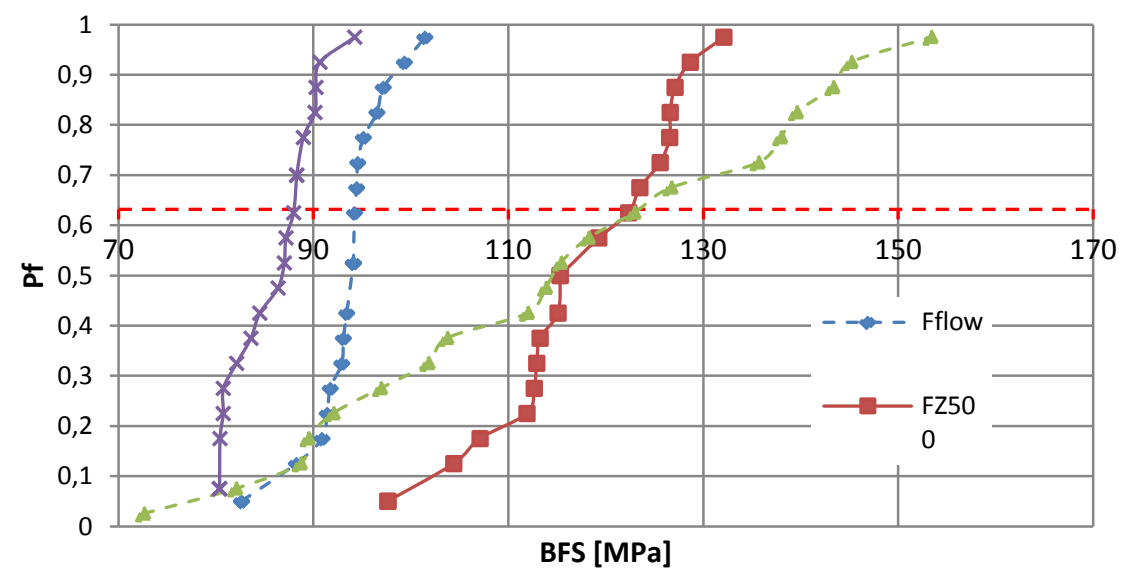

Fig. 3 Failure function of the bending strength of studied composites 


\section{Conclusions}

- Ceramic-polymer composites have a complex internal structure and usually have some defects (flaws). The defects initiate development of the failures. Application durability is limited by developing failures (resistance of material with higher initial unreliability decreases faster), therefore it is directly connected with internal structure of the composite and load history.

- Descriptive statistics determined based on the results indicate lower strength of "flow" type composites comparing to other studied composites. Similarly, scale parameter of Weibull distribution is lower for "flow" type composites. It is related to lower filler particles content in those materials.

- No significant difference in strength between material with nanoparticles (FZ500) and microhybrid composite (F2) has been observed. Most probably it is related to similarity of materials structures, where the clusters are present in the micro scale of nanoparticles.

- Higher Weibull modulus value of "flow" type composites indicates its probable higher reliability, in the population characterized with lower structure entropy. Additionally, it can be expected that the number and sizes of structural defects in "flow" type composites are lower than in case of other studied materials.

- The results of studies and conducted analysis confirmed necessity of extending strength studies with reliability analysis in order to gain generic data on the characteristics of the studied composites.

\section{Literature}

[1] Ban S., Hasegawa J., Anusavice K.J. Effect of loading conditions on bi-axial flexture strength of dental cements. Dental Materials 1992;8:100-104.

[2] Brunthater A., Konig F., Lucas T., Sperr W., Schedle A. Longevity of direct resin composite restorations in posterior teeth. Clinical Oral Investigations 2003;7:63-70.

[3] Butikofer L., Stawarczyk B. Ross M. Two regression methods for estimation of a two-parameter Weibull distribution for reliability of dental materials. Dental Materials 2015;31:e33-e50.

[4] Davies D.G.S.: The statistical approach to engineering design in ceramics. Proceedings of the British Ceramic Society 1973;22:429-452.

[5] Hahnel S., Dowling A.H., El-Safty S., Fleming G.J.P. The influence of monomeric resin and filler characteristics on the performance of experimental resin-based composites (RNCs) derived from a commercial formulation. Dental Materials 2012;28:416-423. 
Study of ceramic-polymer composites reliability based on the bending strength test Ocena niezawodności kompozytów ceramiczno-polimerowych na podstawie...

[6] Kelly J.R. Perspectives on strength. Dental Materials 1995;11:103-111.

[7] Krzyżak A., Vališ D. Selected safety aspects of polymer composites with natural fibres. Safety and Reliability: Methodology and Applications Nowakowski et al.(Eds). Taylor \& Francis Group, London 2015. ISBN 978-1138-02681-0.

[8] Migdalski J.: Inżynieria niezawodności. Poradnik. Wyd. ATR ZETOM, Warszawa 1992.

[9] Niewczas A.M., Pieniak D., Ogrodnik P. Reliability analysis of strength of dental composites subjected to different photopolymerization procedures. Eksploatacja i Niezawodność - Maintenace and Reliability 2012;14:249-255.

[10] Palin W.M., Fleming G.J.P., Marquis P.M. The reliability of standardized flexure strength testing procedures for light-activated resin-based composite. Dental Materials 2005;21:911-919.

[11] Pick B., Meira J.B.C., Driemeier L., Braga R.R. A critical view on biaxial and short-beam uniaxial flexural strength tests applied to resin composites using Weibull, fractographic and finite element analyses. Dental Materials, 2010;26:83-90.

[12] Pieniak D., Niewczas A.M., Walczak M., J. Zamościńska. Influence of photopolymerization parameters on the mechanical properties of polymerceramic composites applied in the conservative dentistry. Acta of Bioengineering and Biomechanics, 2014:16:29-35.

[13] PN-EN ISI 6872:2009. Stomatologia-Materiały ceramiczne.

[14] PN-EN ISO 4049:2010. Stomatologia. Materiały polimerowe do odbudowy.

[15] Rodrigues Junior S.A., Ferracane J.L., Bona A.D. Flexural strength and Weibull analysis of a microhybrid and a nanofill composite evaluated by 3 and 4-point bending tests. Dental materials 2008;24:426-431.

[16] Stanley P., Fessler H., Sivil A.D.: An engineer's approach to the prediction of failure probability in brittle components. Proceedings of the British Ceramic Society 1973;22:453-87.

[17] St-Georges A.J. Swift E.J., Thompson J.Y. Heymann H.O. Irradiance effects on the mechanical properties of universal hybrid and flowable hybrid resin composites. Dental Materials 2003;19:406-413.

[18] Van Nieuwenhuysen J.P., D’Hoore W., Carvalho J., Qvist V. Long-term evaluation of extensive restorations in permanent teeth. Jurnal of Dentistry 2003;31:395-405.

[19] Wilson K.S., Zhang K., Antonucci J.M. Systematic variation of interfacial phase reactivity in dental nanocomposites. Biomaterials 2005;26:5095-5103. 


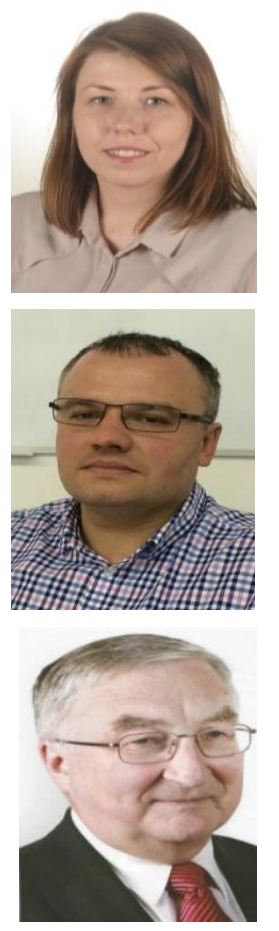

Cpt. M.Sc. Eng. Agata Walczak - graduated from the Faculty of Firefighting Safety Engineering of Main School of Fire Services in Warsaw. Since 2011 she is employed as a teaching assistant at the Division of Applied Mechanics of Main School of Fire Services in Warsaw.

Ph.D. Eng. Daniel Pieniak - graduated from the Faculty of Mechanics of Lublin University of Technology, where in 2010 he earned a doctorate in technical sciences in the field of construction and operation of machines. Since 2006 he is an employee of the Division of Applied Mechanics of the Main School of Fire Services in Warsaw. He carries out operational research of strength and failure mechanisms of structural and functional materials, as well as components of firefighting equipment and individual protections at the conditions of thermal and mechanical exposures.

Prof. Andrzej Niewczas, PhD Eng. He is professor Faculty of Mechanical Engineering Technical University of Lublin. In his research he Deals with problems connected with construction and maintenance machines and transport systems. Additionally professor Niewczas is a President of the Polish Maintenance Society.

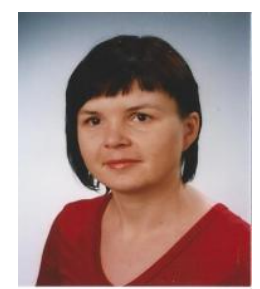

Agata Niewczas, MD PhD, Associate Professor at the Department of Conservative Dentistry with Endodontic Medical University of Lublin. She is involved in the field of research of composite materials used in dentistry, laboratory testing methods of fatigue life of the tooth-filling system and clinical trials durability testing of dental fillings.

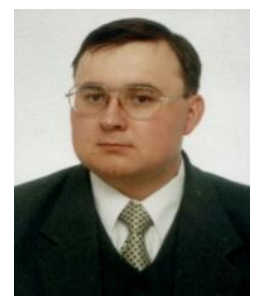

PhD. Eng. Pawet Kordos is a assistant professor at the Department of Combustion Engines, Institute of Transport, Combustion Engines and Ecology at the Lublin Univerisity of Technology. He graduated from Lublin University of Technology, Faculty of Mechanics. He earned a master degree in Mechanics and Mechanical Engineering, specialty Cars and Tractors and a $P h D$ degree in the area of Construction and Maintenance Engineering. His research area include bench testing of internal combustion engines, combustion simulation studies, reliability of mechanical systems, durability and abrasion of dental materials studies, design and research of the means of transport. Teaching activities include lectures in the fields of Mechanics and Mechanical Engineering and Transport at the Faculty of Mechanical Engineering. 
Study of ceramic-polymer composites reliability based on the bending strength test Ocena niezawodności kompozytów ceramiczno-polimerowych na podstawie... 